\title{
Kesadahan Air Media Pemeliharaan dan Pengaruhnya Terhadap Kualitas Produk Kepiting Soka
}

\author{
Sunaryo, Ali Djunaedi dan Adi Santoso* \\ Departemen IImu Kelautan, Fakultas Perikanan dan IImu Kelautan, Universitas Diponegoro \\ JI. Prof. Soedarto, SH. Kampus UNDIP Tembalang, Semarang 50275 \\ Email : adisantoso1959@gmail.com
}

\begin{abstract}
Mangrove crabs (Scylla serrata Forsskål, 1775) is one of the biological resources of the sea, that have economically important value and has been widely cultivated by traditional farmers to meet food needs in both the local and export markets. But the resulting quality of soft shell crab is not optimal. Quality is determined by the hardness of crab carapace after moulting. Approach to problem solving can be done through the research process of the aquatic organisms to their environment adaptation. This research was aimed to acknowledge the influence of the difference in water softening against time duration the hardening rate of the crabs carapace. This research had done in the area of brackishwater pond in the village of Mojo, Ulujami, Pemalang Regency during 8 months. Animal test used a Mangrove crab (S. serrata Forsskål, 1775), the weight size of $80-150 \mathrm{~g}$, individually kept in plastic boxes $(30 \times 20 \mathrm{x}$ $25 \mathrm{~cm}), 15$ pieces per $\mathrm{m} 2$ density. Research was carried out using case study method. The observation parameters of research was aimed at the water softening and calcium content of rearing water media and body fluids of mangrove crabs, and time duration of carapace hardening. The data obtained from the results of the measurement and calculation of the research parameters of each sampling, include: carapace hardening response due to differences in water softening and calcium content in the rearing media as well as calcium content in the body fluid of the mangrove crab was analyzed using t-test. Observation on the research results showed that the process of soft shell crab production using rearing media of brackishwater and freshwater, each was respectively difference in the containing value of water softening and calcium content $(p<0.01)$. The water softening and calcium content of mangrove crabs as well as the calcium content of body fluid of the mangrove crab to response of time duration the carapace hardening on the mangrove crab after moulting as a whole indicated very significant difference $(p<0.01)$. But the results of the statistical analysis of calcium content in the body fluid of mangrove crab with the environmental rearing water media on each individual habitat suggested not significant difference $(p \geq$ 0.01). The conclusions of these research, i.e. water softening and calcium content of the rearing water of mangrove crab was the determining factor in the quality of the soft shell crab product. On the occasion research was advised to do optimization of water softening in the rearing crab, so resulting highly quality product of soft shell crab.
\end{abstract}

Keywords : Calcium, Carapace Hardening, The Quality of Soft Shell Crab, Water Softening.

\begin{abstract}
Abstrak
Kepiting bakau (Scylla serrata Forsskål, 1775) merupakan salah satu sumber daya hayati laut yang mempunyai nilai ekonomis penting dan banyak dibudidayakan oleh petani tradisional untuk memenuhi kebutuhan pangan baik di pasar lokal maupun ekspor. Namun kualitas kepiting soka yang dihasilkan belum optimal. Kualitas kepiting soka sangat ditentukan oleh tingkat kekerasan kulit kepiting setelah moulting. Pendekatan pemecahan masalah ini dapat dilakukan melalui penelitian proses adaptasi organisme perairan terhadap lingkungannya. Penelitian ini bertujuan untuk mengetahui pengaruh perbedaan kesadahan terhadap lama waktu kecepatan pengerasan carapace kepiting. Penelitian dilakukan
\end{abstract}


selama 8 bulan di pertambakan Desa Mojo, Kecamatan Ulujami, Kabupaten Pemalang. Hewan uji yang dipergunakan berupa Kepiting Bakau (S. serrata Forsskål, 1775), berat 80 - 150 g, dipelihara pada bok plastik $(30 \times 20 \times 25 \mathrm{~cm})$ secara seluler, padat penebaran 15 ekor per m2. Penelitian dilakukan dengan menggunakan metode studi kasus. Parameter penelitian ditujukan pada kesadahan dan kandungan kalsium air media pemeliharaan dan cairan tubuh Kepiting Bakau serta lama waktu pengerasan carapace. Data yang didapatkan dari hasil pengukuran dan perhitungan parameter penelitian pada tiap - tiap pengambilan sampel, meliputi: respon pengerasan carapace akibat perbedaan kesadahan dan kandungan kalsium dalam media air pemeliharaan serta kandungan kalsium dalam tubuh kepiting bakau dianalisis dengan menggunakan uji $t$ tes. Hasil pengamatan di dalam penelitian menunjukkan bahwa proses produksi kepiting soka menggunakan media pemeliharaan air tambak dan tawar, masing - masing mengandung nilai kesadahan dan kandungan kalsium yang berbeda $(p<0,01)$. Kandungan kesadahan dan kalsium air media pemeliharaan Kepiting Bakau pada media air pemeliharaan yang berbeda menunjukkan perbedaan sangat signifikan terhadap respon waktu pengerasan carapace Kepiting Bakau setelah moulting $(p<0,01)$. Namun hasil analisis statistik kandungan kalsium cairan tubuh kepiting bakau dengan lingkungan media air pemeliharaan pada masing - masing habitat menunjukkan tidak adanya perbedaan yang sangat nyata $(p \geq 0,01)$. Kesimpulan penelitian ini, yaitu kesadahan dan kandungan kalsium air pemeliharaan merupakan faktor penentu kualitas produk kepiting soka. Pada penelitian selanjutnya disarankan untuk mengoptimalkan kesadahan sehingga dihasilkan produk kepiting soka berkualitas tinggi.

Kata Kunci : Kalsium, Kesadahan, Kualitas Kepiting Soka, Pengerasan Carapace

\section{PENDAHULUAN}

Kepiting bakau (Scylla serrata Forsskål, 1775) merupakan salah satu sumber daya hayati laut yang sebarannya sangat luas dan berlimpah di perairan Indonesia. Kepiting bakau merupakan salah satu jenis Crustacea yang memiliki nilai ekonomis penting dan telah banyak dibudidayakan oleh petani tradisional untuk memenuhi kebutuhan pangan baik di pasar lokal maupun ekspor. Menurut BPS (2016) dinyatakan bahwa pasar ekspor kepiting ke beberapa negara, yaitu: Taiwan, China, Malaysia, Jepang, Amerika, Italy dan Singapore cukup besar. Jumlah ekspor Kepiting Bakau sebesar 109.624,4 ton pada tahun 2015 dan mengalami peningkatan per tahun sebesar $17,74 \%$ per tahun dari 58.091,8 ton pada tahun 2010 (BPS, 2016). Suroso (2016) menyatakan bahwa permintaaan kepiting bakau untuk tujuan ekspor ke negara Jepang sebesar 0,3 ton per hari dan ke Amerika sebesar 0,4 ton per hari. Namun para pembudidaya di kawasan tambak tersebut belum bisa memenuhi permintaan yang dibutuhkan oleh konsumen.
Rendahnya produksi yang dihasilkan dari kegiatan budidaya ini dikarenakan di dalam proses produksinya masih mengalami berbagai kendala. Salah satu permasalahan yang ada di dalam kegiatan usaha budidaya, yakni kualitas kepiting soka yang dihasilkan masih rendah. Kualitas kepiting soka sangat ditentukan oleh tingkat kekerasan kulit kepiting setelah moulting. Semakin keras kulit kepiting yang dihasilkan, maka semakin rendah kualitas produk yang dihasilkan. Pengukuran tingkat kekerasan kulit kepiting dapat dilakukan dengan pengamatan tubuh kepiting secara morphologis. Kecepatan pengerasan kulit kepiting soka sangat ditentukan oleh berbagai faktor, antara lain: kandungan kalsium dalam air dan dalam tubuh organisme, lama waktu perendaman organisme di dalam media pemeliharaan. Pendekatan pemecahan masalah ini dapat dilakukan melalui penelitian proses adaptasi organisme perairan terhadap lingkungannya. Target khusus yang ingin dicapai dari penelitian ini adalah mengetahui hubungan kesadahan air media, lama perendaman dalam larutan hyper-,iso- dan hyposmotik dengan kecepatan pengerasan kulit pada kondisi 
lingkungan budidaya sehingga dapat dipergunakan untuk pengembangan produksi kepiting soka terutama peningkatan kualitas soka.

Penelitian ini bertujuan untuk mengetahui pengaruh perbedaan kesadahan air media pemeliharaan, kandungan kalsium dalam air media pemeliharaan dan kandungan kalsium dalam cairan plasma tubuh kepiting terhadap lama waktu kecepatan pengerasan carapace kepiting.

\section{MATERI DAN METODE PENELITIAN}

Penelitian dilakukan dalam waktu 8 bulan, di kawasan pertambakan di Desa Mojo, Kecamatan Ulujami, Kabupaten Pemalang. Kepiting Bakau (S. serrata Forsskål, 1775) sebagai hewan uji, diperoleh dari alam dan dipelihara pada kondisi lingkungan budidaya. Kepiting Bakau yang dipergunakan berjenis kelamin jantan dan betina, berat antara 80 - $150 \mathrm{~g}$, dengan padat penebaran 15 ekor per m2. Kepiting Bakau dipelihara pada bok plastik (30 × $20 \times 25 \mathrm{~cm})$, dengan menerapkan pemeliharaan sistim seluler untuk mencegah kanibalisme (Gambar 1). Pemeliharaan dengan menggunakan air laut yang sebelumnya difilter dengan menggunakan saringan plankton net ukuran $200 \mu \mathrm{m}$. Kepiting Bakau dipelihara pada kondisi lingkungan salinitas 10-33 ppt, suhu antara $27-33^{\circ} \mathrm{C}$, $\mathrm{pH} 7$ - 8, oksigen lebih besar $3 \mathrm{mg} / \mathrm{L}$. Kepiting Bakau diberi pakan ikan rucah dari jenis ikan Petek (Famili Leiognathidae) secara ad libitum. Pemberian pakan dilakukan dua kali sehari pada pagi hari dan saat hari mulai gelap dengan perbandingan $30 \%$ dan $70 \%$ dari sejumlah pakan yang diberikan. Penentuan ini dilakukan berdasarkan sifat - sifat yang dimiliki oleh Kepiting Bakau, yaitu sebagai hewan nocturnal.

Parameter pengamatan di dalam penelitian ditujukan pada kesadahan air media pemeliharaan kepiting dan dalam cairan tubuh Kepiting Bakau. Pengukuran tingkat kesadahan dilakukan pada saat kepiting mengalami moulting. Selain itu diukur pula lama waktu terjadinya pengerasan cangkang. Pengukuran pengerasan cangkang diamati setiap 10 menit sekali selama moulting. Selain itu juga dilakukan pengukuran kualitas air media pemeliharaan Kepiting Bakau, meliputi: suhu, salinitas, oksigen, $\mathrm{pH}$, muatan padatan tersuspensi, kesadahan, kalsium, kecerahan, ammonia dan nitrit sebagai faktor penunjang.

Data yang didapatkan dari hasil pengukuran dan perhitungan parameter penelitian pada tiap - tiap pengambilan sampel, meliputi: respon pengerasan carapace akibat perbedaan kesadahan dan kandungan kalsium dalam media air pemeliharaan serta kandungan kalsium dalam tubuh kepiting bakau dianalisis dengan menggunakan uji t tes (Steel and Torrie, 1980; Sudjana, 1982).

\section{HASIL DAN PEMBAHASAN}

\section{Kualitas Air Media Pemeliharaan Kepiting Bakau}

Hasil pengukuran beberapa parameter kualitas air pemeliharaan Kepiting Bakau untuk memproduksi kepiting soka secara umum masih menunjukkan kisaran yang cukup baik untuk mendukung kehidupan Kepiting Bakau yang dipelihara di kawasan pertambakan (Effendi, 2003; William, 2003; Stevens, 2009), sebagai berikut: Suhu 30,58 \pm sd $1,44{ }^{\circ} \mathrm{C}$, Salinitas $30 \pm \mathrm{sd} 0,00 \mathrm{~g} / \mathrm{L}$, Oksigen $4,47 \pm s d 0,153 \mathrm{mg} / \mathrm{L}, \mathrm{pH} \quad 6,73 \pm$ sd 0,06, Nitrit 0,033 \pm sd 0,003 $\mathrm{mg} / \mathrm{L}$, Ammonia 0,320 \pm sd 0,001 mg/L, MPT 26,42 $\pm \mathrm{sd} 0,954 \mathrm{mg} / \mathrm{L}$, Kecerahan 36,33 $\pm \mathrm{sd} 3,21$ $\mathrm{cm}$, Struktur Tanah: Liat Pasir Berlumpur; liat $>40 \%$, lempung liat 50-60\%, lempung 7-27 $\%$, pasir $<12 \%$, pH tanah 5,5-7,5.

\section{Kesadahan Air Media Pemeliharaan Kepiting Bakau}

Proses produksi yang dilakukan untuk menghasilkan kepiting soka menggunakan air media pemeliharaan yang berbeda - beda, yaitu: pada tahap penggemukan dan perangsangan moulting menggunakan media pemeliharaan air tambak dengan salinitas $30 \mathrm{~g} / \mathrm{L}$ dan pemeliharaan setelah moulting 
menggunakan air tawar dengan salinitas 5 $\mathrm{g} / \mathrm{L}$. Kedua jenis media air pemeliharaan Kepiting Bakau untuk memproduksi kepiting soka di kawasan pertambakan tersebut mempunyai tingkat kesadahan air, sebagai berikut: Air tambak 660,72 $\mathrm{mg} / \mathrm{L} \pm$ SD $24,95 \mathrm{mg} / \mathrm{L}$, air tawar 126,37 $\mathrm{mg} / \mathrm{L} \pm \mathrm{SD} 0,54 \mathrm{mg} / \mathrm{L}$.

Hasil analisis statistik kandungan kesadahan air media pemeliharaan Kepiting Bakau untuk produksi kepiting soka menunjukkan adanya perbedaan yang sangat signifikan $(p<0,01)$. Dengan demikian dapat dinyatakan bahwa kandungan kesadahan air media pemeliharaan Kepiting Bakau untuk produksi kepiting soka yang dilakukan dengan menggunakan air tambak menunjukkan tingkat kesadahan yang lebih tinggi, yaitu dicapai sebesar 660,72 $\mathrm{mg} / \mathrm{L} \pm \mathrm{SD} 24,95 \mathrm{mg} / \mathrm{L}$ dibandingkan dengan air tawar, yaitu sebesar 126,37 $\mathrm{mg} / \mathrm{L} \pm \mathrm{SD} 0,54 \mathrm{mg} / \mathrm{L}$.

Hasil analisis statistik kandungan kesadahan air media pemeliharaan Kepiting Bakau untuk produksi kepiting soka terhadap respon waktu pengerasan carapace Kepiting Bakau menunjukkan adanya perbedaan yang sangat signifikan $(p<0,01)$. Dengan demikian dapat dinyatakan bahwa kandungan kesadahan air media pemeliharaan Kepiting Bakau untuk produksi kepiting soka yang dilakukan dengan menggunakan air tambak menunjukkan waktu yang lebih cepat, yaitu dicapai dalam waktu 3.216 menit \pm SD 115,93 menit dibandingkan dengan air tawar, yaitu sebesar 3.720 menit \pm SD 204,06 menit (Gambar 1).

\section{Kalsium Media Air Pemeliharaan Kepiting Bakau}

Hasil pengamatan proses pemeliharaan kepiting bakau untuk produksi kepiting soka menunjukkan bahwa jenis media air pemeliharaan Kepiting Bakau untuk memproduksi kepiting soka di kawasan pertambakan tersebut mempunyai kandungan kalsium, sebagai berikut: $409,99 \mathrm{mg} / \mathrm{L} \pm \mathrm{SD} 1,81$ $\mathrm{mg} / \mathrm{L}$ dibandingkan dengan air tawar, yaitu sebesar 363,042 mg/L \pm SD 8,85 mg/L.

Hasil analisis statistik kandungan kalsium dalam air media pemeliharaan Kepiting Bakau untuk produksi kepiting soka menunjukkan adanya perbedaan yang sangat signifikan $(p<0,01)$. Dengan demikian dapat dinyatakan bahwa kandungan kalsium dalam air media pemeliharaan Kepiting Bakau untuk produksi kepiting soka yang dilakukan

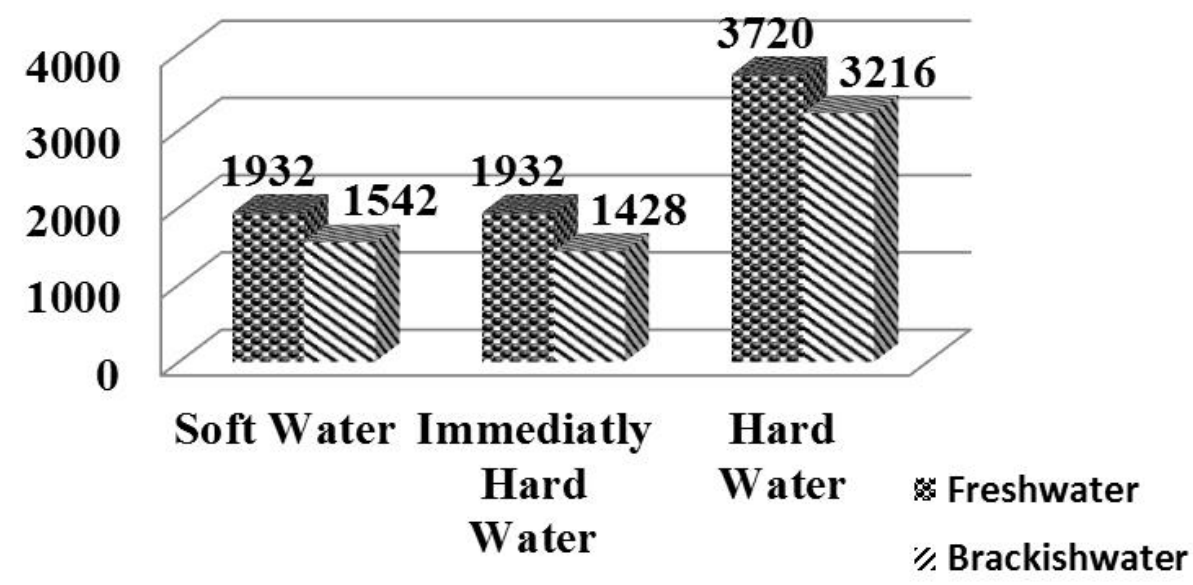

Gambar 1. Kesadahan Air Media Pemeliharaan Kepiting Bakau dan Waktu Pengerasan Karapas Kepiting Bakau Setelah Moulting. Keterangan: Air Tawar (Rerata Kesadahan $=126,37 \mathrm{mg} / \mathrm{L} \pm \mathrm{SD} 0,54 \mathrm{mg} / \mathrm{L}$ ); Air Tambak (Rerata Kesadahan= $660,72 \mathrm{mg} / \mathrm{L} \pm \mathrm{SD} 24,95 \mathrm{mg} / \mathrm{L})$. 


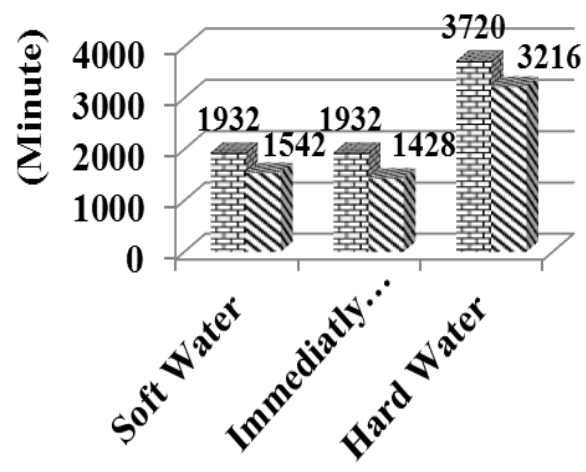

\section{宦 Low Calsium \\ \%.High Calsium}

Gambar 2. Perbedaan Kandungan Kalsium Air Media Pemeliharaan Kepiting Bakau dan Waktu Pengerasan Carapace Kepiting Bakau Setelah Moulting. Keterangan: Air Tawar (Rerata Kandungan Kalsium $=363,042 \mathrm{mg} / \mathrm{L} \pm \mathrm{SD} 8,85 \mathrm{mg} / \mathrm{L}$ ); Air Tambak (Rerata Kandungan Kalsium $=409,99 \mathrm{mg} / \mathrm{L} \pm \mathrm{SD} 1,81 \mathrm{mg} / \mathrm{L}$ ).

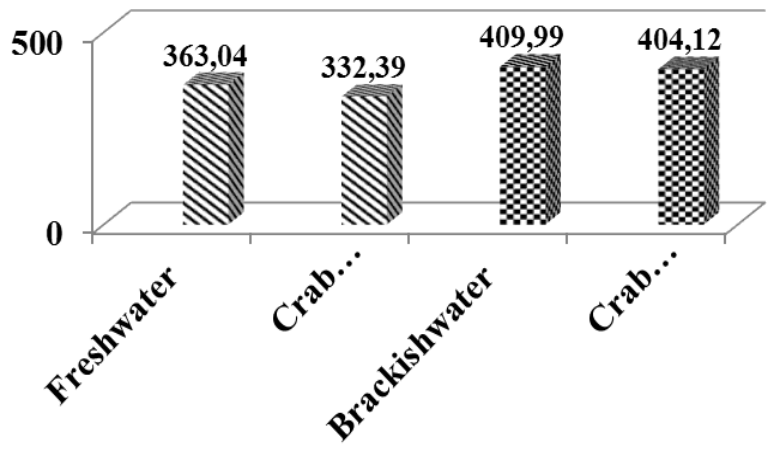

Gambar 3. Kandungan Kalsium Cairan Tubuh Kepiting Bakau dan Lingkungan Media Pemeliharaan (mg/L).

dengan menggunakan air tambak mempunyai kandungan kalsium yang lebih tinggi, yaitu sebesar 409,99 mg/L \pm SD $1,81 \mathrm{mg} / \mathrm{L}$ dibandingkan dengan air tawar, yaitu sebesar $363,042 \mathrm{mg} / \mathrm{L} \pm \mathrm{SD} 8,85 \mathrm{mg} / \mathrm{L}$.

Hasil analisis statistik kandungan kalsium air media pemeliharaan Kepiting Bakau untuk produksi kepiting soka terhadap respon waktu pengerasan carapace Kepiting Bakau setelah moulting menunjukkan adanya perbedaan yang sangat signifikan $(p<0,01)$. Dengan demikian dapat dinyatakan bahwa kandungan kalsium air tambak media pemeliharaan Kepiting Bakau yang dipergunakan untuk produksi kepiting soka dapat memberikan respon terhadap waktu pengerasan carapace Kepiting
Bakau yang lebih cepat, yaitu dicapai dalam waktu 3.216 menit \pm SD 115,93 menit dibandingkan dengan air tawar, yaitu sebesar 3.720 menit \pm SD 204,06 menit (Gambar 2).

Hasil pengukuran kandungan kalsium di dalam cairan tubuh kepiting bakau yang dipelihara di dalam media air pemeliharaan yang berbeda untuk produksi kepiting soka ditunjukkan pada Gambar 3. Kepiting Bakau yang dipelihara pada media air tambak mempunyai kandungan kalsium yang hampir sama dengan lingkungannya, yaitu sebesar $404,122 \mathrm{mg} / \mathrm{L} \pm \mathrm{SD}$ 15,83 mg/L. Demikian juga kandungan kalsium di dalam cairan tubuh kepiting bakau yang dipelihara di dalam media air tawar mempunyai kandungan kalsium yang hampir sama 
dengan lingkungannya, yaitu sebesar $332,394 \mathrm{mg} / \mathrm{L} \pm$ SD $21,98 \mathrm{mg} / \mathrm{L}$.

Hasil analisis statistik kandungan kalsium dalam cairan tubuh Kepiting Bakau untuk produksi kepiting soka yang dipelihara pada media air pemeliharaan yang berbeda menunjukkan adanya perbedaan yang sangat signifikan $(p<0,01)$. Dengan demikian dapat dinyatakan bahwa kandungan kalsium dalam cairan tubuh Kepiting Bakau untuk produksi kepiting soka yang dilakukan dengan menggunakan air tambak mengandung kalsium yang lebih tinggi, yaitu sebesar 404,122 mg/L \pm SD 15,83 $\mathrm{mg} / \mathrm{L}$ dibandingkan dengan air tawar, yaitu sebesar 332,394 mg/L \pm SD 21,98 $\mathrm{mg} / \mathrm{L}$ (Gambar 3). Namun hasil analisis statistik kandungan kalsium cairan tubuh kepiting bakau dengan lingkungan media air pemeliharaan pada masing - masing habitat menunjukkan tidak adanya perbedaan yang sangat nyata $(p \geq 0,01)$. Dengan demikian dapat dinyatakan bahwa kondisi kandungan kalsium cairan tubuh dengan lingkungan kehidupannya mempunyai kesamaan (Gambar 3).

\section{Kualitas Produk Kepiting Soka}

Kualitas produk kepiting soka ditentukan oleh berbagai macam faktor. Adapun faktor yang menentukan kualitas produk kepiting soka, yaitu antara lain: tingkat kekerasan carapace, ukuran besar kecilnya kepiting dan kelulushidupan kepiting. Faktor penentu tingkat kualitas produk kepiting soka tersebut sangat ditentukan oleh pelaksanaan managemen produksi di dalam kegiatan budidaya dan paska panennya. Faktor pengelolaan program kegiatan produksi yang penting, antara lain: adalah pengelolaan kualitas air media pemeliharaan. Faktor pengelolaan kualitas air media pemeliharaan yang sangat berpengaruh terhadap kualitas produk kepiting soka, di antaranya adalah faktor penentuan tingkat kesadahan air media pemeliharaan kepiting bakau. Selain itu faktor pertumbuhan dan kelulushidupan juga merupakan faktor penting yang dapat menentukan kualitas dan keberhasilan produk pada kegiatan produksi kepiting soka yang sangat dipengaruhi oleh faktor eksternal, terutama media pemeliharaan kepiting bakau.

Media air pemeliharaan kepiting bakau yang dipergunakan untuk memproduksi kepiting soka mempunyai tingkat kesadahan yang berbeda. Perbedaan nilai kesadahan air media pemeliharaan kepiting bakau untuk memproduksi kepiting soka sangat berpengaruh terhadap kecepatan pengerasan carapace kepiting bakau yang pengaruhnya berakibat lanjut terhadap kualitas kepiting soka. Hal ini dapat dilihat pada Gambar 1 yang menunjukkan waktu pengerasan carapace kepiting bakau sangat berkaitan erat dengan perbedaan media air pemeliharaan yang dipergunakan untuk memproduksi kepiting soka. Berdasarkan Gambar 1 tersebut menunjukkan bahwa kepiting moulting yang dipelihara pada media air pemeliharaan yang berbeda, yaitu pada air tambak dan air tawar menghasilkan kecepatan pengerasan carapace yang berbeda - beda. Hal ini terbukti dari hasil uji $\dagger$ dari kedua variabel tersebut yang menunjukkan bahwa respon kecepatan pengerasan carapace kepiting bakau setelah moulting berbeda - beda tergantung dari media pemeliharaan yang dipergunakan. Pada pemeliharaan media air tawar kepiting bakau mengalami pengerasan carapace yang lebih lama dibandingkan pada proses pemeliharaan di air tambak. Hal ini dapat dilihat secara jelas seperti pada Gambar 1, bahwa proses pemeliharaan di air tawar pengerasan carapace kepiting bakau dicapai dalam waktu 3.216 menit \pm SD 115,93 menit, sedangkan pada proses pemeliharaan di air tambak pengerasan carapace kepiting bakau dicapai dalam waktu 3.720 menit \pm SD 204,06 menit. Pada proses pemeliharaan di air tawar proses pengerasan carapace kepiting bakau dicapai lebih lama dibanding pada proses pemeliharaan di air tambak.

Sesuai dengan berbagai pendapat dari para peneliti (Richard, 1951 dalam 
Stevenson, 1985; Neville, 1975 dalam Stevenson, 1985) dinyatakan bahwa berbagai jenis kepiting yang sedang mengalami moulting memerlukan kalsium yang diambil dari lingkungannya guna mengeraskan carapacenya. Waktu kejadian pengerasan carapace ini sangat bervariasi dan sangat tergantung kepada lingkungan perairan tempat kehidupannya dan jenis organisme (Mill et al., 1976; Reid, 1975 dalam Stevenson, 1985; Travis, 1955 dalam Stevenson, 1985; Melnick et al.,1995; Hicks dan Johnson, 1999; Hebert et al., 2002; Stevens, 2009) (Gambar 2). Apabila dilihat dari media air pemeliharaan yang dipergunakan untuk produksi kepiting soka yang berupa air tawar, menunjukkan bahwa dari hasil penelitian yang telah dilakukan mempunyai nilai kesadahan yang lebih rendah dibandingkan media air tambak. Berdasarkan pendapat Bahtiar dan Agung (2008), air sadah didefinisikan sebagai air yang mengandung mineral - mineral tertentu umumnya ion - ion kalsium dan magnesium dalam bentuk garam karbonat. Berdasarkan Gambar 2 tersebut, maka air tawar yang dipergunakan sebagai media air pemeliharaan kepiting bakau untuk memproduksi kepiting soka mempunyai kandungan nilai kalsium yang lebih rendah dibandingkan media air pemeliharaan yang berupa air tambak. Dengan demikian ketersediaan unsur kalsium yang diperlukan untuk pengerasan carapace kepiting bakau pada media air tawar kurang sesuai dalam memenuhi kebutuhan yang diperlukan oleh kepiting bakau untuk proses kalsifikasi, sehingga kepiting bakau yang dipelihara pada kondisi ini mempunyai carapace lunak dalam waktu yang relatif lama. Hal ini terbukti dapat dilihat secara jelas pada Gambar 2 yang menunjukkan bahwa kepiting bakau yang dipelihara pada kondisi air tawar pada saat setelah moulting mempunyai tingkat kelunakan carapace yang relatif lebih lama, yaitu sebesar 1.932 menit \pm SD 37,95 menit dibanding pada air tambak, yaitu sebesar 1.542 menit \pm SD 109,34 menit.

Menurut pendapat Penzlin (1996) dinyatakan bahwa jenis - jenis crustacea termasuk kepiting merupakan hewan yang selalu menyesuaikan diri dengan kondisi lingkungan sekitarnya, baik terhadap kondisi perubahan suhu, salinitas, $\mathrm{pH}$, kandungan oksigen dalam air, kandungan nitrit, amonium, amonia dalam air maupun kandungan unsur unsur penting lainnya. Hal ini tampak jelas terlihat seperti yang terjadi pada Gambar 3, menunjukkan bahwa kepiting bakau pada saat setelah moulting yang dipelihara pada lingkungan media air tawar dengan kandungan kadar kalsium sebesar $364,25 \mathrm{mg} / \mathrm{L} \pm \mathrm{SD} 14,07 \mathrm{mg} / \mathrm{L}$ di dalam cairan tubuhnya mengandung unsur kalsium yang mendekati kondisi lingkungan sekitarnya, yaitu sebesar 332,94 $\mathrm{mg} / \mathrm{L} \pm \mathrm{SD} 21,98 \mathrm{mg} / \mathrm{L}$. Demikian juga pada kondisi lingkungan yang mempunyai kandungan unsur kalsium yang lebih tinggi, seperti pada lingkungan kawasan perairan tambak yang mengandung unsur kalsium sebesar 409,56 mg/L \pm SD 2,91 $\mathrm{mg} / \mathrm{L}$, di dalam cairan tubuhnya mengandung unsur kalsium yang mendekati kondisi lingkungan sekitarnya, yaitu sebesar 404,122 mg/L \pm SD 15,83 $\mathrm{mg} / \mathrm{L}$.

Kepiting bakau selalu menyesuaikan diri dengan kondisi lingkungan sekitarnya, sesuai dengan sifat - sifatnya sebagai hewan "osmoconformer". Hardy et al. (1994) juga menegaskan bahwa kepiting dalam kondisi moulting mempunyai konsentrasi osmotik cairan plasma yang tinggi baik terhadap air laut maupun air laut yang telah mengalami pengenceran. Cheng et al. (2001) dan Cheng et al. (2002), menjelaskan bahwa tingginya protein hemolympha, osmolality, $\mathrm{Cl}^{-}, \mathrm{Na}^{+}$ dan $\mathrm{K}^{+}$pada Macrobrachium rossenbergii dan Litopenaeus vannamei selama masa intermolt dan awal moulting dikaitkan dengan pengambilan air pada saat moulting.

Sesuai dengan sifat - sifat yang dimiliki kepiting bakau dalam menyesuaikan diri dengan lingkungannya tersebut, maka dalam memenuhi kebutuhan unsur - unsur penting yang diperlukan untuk mendukung kehidupannya dilakukan melalui proses osmotik. Proses masuknya unsur - unsur 
penting, seperti ion kalsium ke dalam cairan sel tubuhnya dilakukan melalui pemanfaatan perbedaan tekanan osmotik dari kedua lingkungan yang berbeda. Selain itu proses masuknya ion ion tersebut dapat dilakukan melalui proses transport aktif dari satu lingkungan ke lingkungan lainnya. Proses ini sangat dipengaruhi oleh faktor lingkungan lainnya yang terkait, seperti $\mathrm{pH}$, salinitas dan lain sebagainya.

\section{KESIMPULAN}

Berdasarkan berbagai data parameter pengamatan di dalam penelitian yang telah dilakukan kiranya dapat disimpulkan, sebagai berikut:

- Kesadahan air pada media pemeliharaan kepiting bakau yang berbeda mengakibatkan perbedaan respon terhadap waktu pengerasan carapace kepiting bakau yang berefek lanjut pada kualitas produk kepiting soka yang dihasilkan.

- Kandungan kalsium air media pemeliharaan kepiting bakau yang berbeda mengakibatkan perbedaan respon terhadap waktu pengerasan carapace kepiting bakau yang berefek lanjut pada kualitas produk kepiting soka yang dihasilkan.

- Kesadahan media air pemeliharaan kepiting bakau merupakan faktor penting yang sangat menentukan kualitas produk kepiting soka.

\footnotetext{
Berdasarkan hasil penelitian yang menunjukkan bahwa media air pemeliharaan kepiting bakau yang dipergunakan untuk memproduksi kepiting soka mempunyai tingkat kesadahan yang berbeda dan perbedaan nilai kesadahan air media pemeliharaan kepiting bakau untuk memproduksi kepiting soka sangat berpengaruh terhadap kecepatan pengerasan carapace kepiting bakau yang pengaruhnya berakibat lanjut terhadap kualitas kepiting soka, maka pada kesempatan penelitian selanjutnya disarankan untuk melakukan optimasi penelitian kesadahan media pemeliharaan sehingga dihasilkan produk kepiting soka yang mempunyai kualitas tinggi.
}

\section{UCAPAN TERIMAKASIH}

Ucapan Terima Kasih yang sebesar besarnya disampaikan kepada: Direktorat Penelitian dan Pengabdian kepada Masyarakat Direktorat Jenderal Pendidikan Tinggi (DP2M Ditjen Dikti) Kementerian Pendidikan Nasional yang telah memberikan biaya Hibah Penelitian Fundamental. Selain itu disampaikan terima kasih pula kepada Ketua LPPM UNDIP yang telah memberikan kepercayaan dan fasilitasi dalam pelaksanaan penelitian. Segenap rekan yang berpartisipasi di dalam penelitian ini, Tri Wahyu Rahmanto, Anggit dan Kelompok Petani Tambak Desa Mojo, Kecamatan Ulujami, Kabupaten Pemalang diucapkan terima kasih.

\section{DAFTAR PUSTAKA}

Bahtiar, R. \& Agung . 2008. Penurunan kesadahan air menggunakan serbuk sekam padi perlakuan dengan $\mathrm{NaOH}$. Dalam: Seminar Jurusan Kimia FMIPA UNDIP, Jurusan Kimia UNDIP.

BPS, 2016. Data Produksi Kepiting Bakau. Badan Pusat Statistik. Jakarta.

Cheng, W., Liu, C.H., Cheng, C.H., \& Chen, J.C. 2001. Hemolymph oxyhemocyanin, protein, osmolality and electrolyte levels of Macrobrachium rosenbergii in relation to size and molt stage. Aquaculture. 198(3-4): 387-400.

Cheng, W., Liu, C.H., Da-Fun Yan D.F. \& Chen, A.C. 2002. Hemolymph oxyhemocyanin, protein, osmolality and electrolyte levels of whiteleg shrimp Litopenaeus vannamei in relation to size and molt stage. Aquaculture. 211 (1-4):325-339.

Effendi, H. 2003. Telaah Kualitas Air Bagi Pengelolaan Sumberdaya Lingkungan dan Lingkungan Perairan. Penerbit Kanisius. Jakarta $200 \mathrm{HIm}$.

Hardy, D., Munro, J. \& Dutil, J.D. 1994. Temperature and salinity tolerance of the soft-shell and hard-shell male snow crab, Chionoecetes opilio. Aquaculture. 122 (2-3):249-265.

Hebert, M., Benhalima, K., Miron, G. \& Moriyasu, M. 2002. Moulting and growth of male snow crab Chionoecetes opilio (O. Fabricius, 
1788)(Decapoda, Majidae), in the southern gulf of St. Lawrence. Crustaceana. 75(5):671-702.

Hicks, D., \& Johnson, B. A.1999. A device to measure shell hardness of dungeness crabs and trial application in the Kodiak Island, Alaska, Commercial Fishery. North American J. Fish. Man. 19:581-590.

Melnick, C.A., Z. Chen, J.J. \& Mecholsky Jr., 1995. Hardness and toughness of exoskeleton material in the stone crab, Menippe mercenaria. MRS Bulleti. 11:2903-2907.

Mills, B.J., Suter, P., \& Lake, P.S. 1976. The amount and distribution of calcium in the exoskeleton of intermolt crayfish of the genera Engaeus and Geocharax. Aust. J. Mar. Freshwater Res. 27:517523.

Penzlin, H. 1996. Lehrbuch der Tierphysiologie. Gustav Fisher Verlag, Jena. Stuttgart. p 646.
Steel, R.G.D., \& T.H. Torrie. 1980.Principles and Procedures of Statistic. Mc. Graw Hill Book, Co., Inc., New York, 633 p.

Stevens, B.G.2009. Hardening of red king crab Paralithodes camtschaticus (Tilesius, 1815) shells after molting. J. Crustac. Biol. 29(2):157-160.

Stevenson, J.R. 1985. Dinamics of the integument. In. Bliss, D.E., andL.H. Mantel. (Eds.). The Biology of Crustacea. Integument, Pigments and Hormonal Processes. Vol 9. Academic Press, INC. Florida. 2-32 pp.

Sudjana. 1982. Metoda Statistika. Penerbit Tarsito, Bandung. $485 \mathrm{HIm}$.

Suroso Yogi. 2016. Personal Komunikasi. Petani Soka Desa Mojo, Ulujami, Pemalang.

William, A.W., 2003. Aquaculture Site Selection. Kentucky State University Coorporative Extention Progam. Princeton. 